University of Nebraska - Lincoln

DigitalCommons@University of Nebraska - Lincoln

$1-1-1999$

\title{
Midseason Stalk Breakage in Corn As Affected by Crop Rotation, Hybrid, and Nitrogen Fertilizer Rate
}

\author{
Wallace Wilhelm \\ University of Nebraska-Lincoln, wwilhelm1@unl.edu \\ Mark A. Liebig \\ University of Nebraska-Lincoln \\ Gary E. Varvel \\ USDA-ARS, gevarvel@windstream.net \\ Tracy M. Blackmer \\ USDA-ARS
}

Follow this and additional works at: https://digitalcommons.unl.edu/usdaarsfacpub

Part of the Agricultural Science Commons

Wilhelm, Wallace; Liebig, Mark A.; Varvel, Gary E.; and Blackmer, Tracy M., "Midseason Stalk Breakage in Corn As Affected by Crop Rotation, Hybrid, and Nitrogen Fertilizer Rate" (1999). Publications from USDAARS / UNL Faculty. 96.

https://digitalcommons.unl.edu/usdaarsfacpub/96

This Article is brought to you for free and open access by the U.S. Department of Agriculture: Agricultural Research Service, Lincoln, Nebraska at DigitalCommons@University of Nebraska - Lincoln. It has been accepted for inclusion in Publications from USDA-ARS / UNL Faculty by an authorized administrator of DigitalCommons@University of Nebraska - Lincoln. 


\title{
Midseason Stalk Breakage in Corn As Affected by Crop Rotation, Hybrid, and Nitrogen Fertilizer Rate
}

\author{
Wallace W. Wilhelm,* Mark A. Liebig, Gary E. Varvel, and Tracy M. Blackmer
}

\begin{abstract}
In July of 1993 and 1994, southern Nebraska experienced devastating windstorms, with winds estimated to exceed $45 \mathrm{~m} \mathrm{~s}^{-1}$. These storms resulted in severe brittle-snap of corn (Zea mays L.), with stalks breaking near the primary ear node in the basal portion of an elongating internode. In the storm path were several experiments established on a Hord silt loam (Cumulic Haplustolls) to determine the effect of selected management practices (crop rotation, hybrid selection, planting date, and $\mathbf{N}$ fertilization) on nitrate leaching to ground water from irrigated cropland. After the storms, the number of broken plants was determined in these experiments to evaluate how management practices influenced severity of the damage. In 1993, crop rotation, hybrid, planting date, and $\mathbf{N}$ fertilization, and their interactions, all affected the amount of brittle-snap. Treatments that resulted in more rapid growth (optimum to excess $\mathrm{N}$ rates, corn rotated with soybean [Glycine $\max$ (L.) Merr.], and early planting) increased the severity of damage. In continuous corn, $7 \%$ of the plants broke, compared with $33 \%$ for rotated corn; damage ranged from 4 to $33 \%$ among hybrids; and percent broken plants increased quadratically, from $8 \%$ for the $0 \mathrm{~kg} \mathrm{~N} \mathrm{ha}^{-1}$ treatment to $24 \%$ at $\mathrm{N}$ rates equal to or greater than $80 \mathrm{~kg} \mathrm{~N} \mathrm{ha}^{-1}$. Only the hybrid factor was significant in 1994. Amount of brittle-snap was related to stage of development ( $r=0.55, n=160, P<0.001$ ). The great difference in severity of damage among hybrids indicates that the current best management strategy to limit brittle-snap losses is to plant hybrids less prone to breakage. Alternative management strategies, such as late planting, suboptimal $\mathbf{N}$ rates, and continuous cropping of corn, all are known to limit yield regardless of windstorms. There is a need for greater knowledge of cell and tissue characteristics that render hybrids susceptible or resistant to brittle-snap. Also, methods for simulating brittlesnap are needed to foster effective selection for resistant lines in breeding programs.
\end{abstract}

$\mathrm{O}^{\mathrm{s}}$ 8 JULY I993, southern Nebraska experienced a devastating windstorm associated with the passing of a cold front. Winds estimated to exceed $45 \mathrm{~m} \mathrm{~s}^{-1}$ advanced over a 600 - by $160-\mathrm{km}$ region of southern Nebraska from the Colorado to Iowa border, encompassing the primary corn growing area of the state. Most of the corn in this area is grown on irrigated, highly productive soil with realistic yield goals of 11 to 13 $\mathrm{Mg} \mathrm{ha}^{-1}$. The storm caused some property damage and downed many trees and limbs in farmsteads, cities, and towns in the area. Lincoln, NE, reported the loss of 1300 trees and more than 100 utility poles within the city limits (NOAA, 1993). However the greatest, and most difficult damage to assess, was the amount of broken corn stalks in the affected area. To quote from the report in Storm Data (NOAA, 1993), "Crop damage was high in some areas, but it was very difficult to determine dollar amounts."

Abbreviations: CMR, comparative maturity rating; CST, central standard time; MSEA, Management Systems Evaluation Area.

W.W. Wilhelm and G.E. Varvel, USDA-ARS, 119 Keim Hall, Univ. of Nebraska, Lincoln, NE 68583-0934; M.A. Liebig, Dep. of Agronomy, Univ. of Nebraska, Lincoln, NE 68583-0915; and T.M. Blackmer (formerly USDA-ARS), Monsanto, 800 N. Lindbergh Blvd.-R4B, St. Louis, MO 63167. Joint contribution of the USDA-ARS and the Agric. Res. Div. of the Univ. of Nebraska: published as Journal Series no. 12547. Received 25 Mar. 1998. *Corresponding author (wwilhelm@unlinfo.unl.edu).

Published in Agron. J. 91:160-165 (1999). 
The type of damage that occurred in corn fields affected by this storm initially appeared unusual, with stalks breaking near the primary ear node (usually \pm 1 node) in the basal portion of the intercalary meristem (just above the node) of the elongating internode. However, our discussions with extension educators and breeders in the western Corn Belt revealed that the only unusual aspect of this storm was the vast area affected by the winds and the extensive media coverage (e.g., Laukaitis, 1994; Ohle, 1993) that the event received. Midseason stalk breakage from windstorms occurs almost ever year somewhere in the western Corn Belt and is termed brittle-snap or green-snap; the former term will be used throughout this paper. Generally, areas touched by storms are small. However, because of the intense impact that individual events can have for individual growers, many seed companies rate their hybrids for resistance to brittle-snap (Pioneer Hi-Bred Int., 1996).

It is impossible to predict when and where storms will occur, so establishing field experiments to document the influence of management practices on crop susceptibility to wind is also impossible. From time to time, however, research sites are struck by vigorous windstorms at a time when the plants are susceptible to damage. These unfortunate events allow assessment of damage relative to documented management practices and offer the opportunity to learn how cultural practices interact with crop development producing varying levels of loss. Given the windstorms experienced at the research sites, our objective was to evaluate the effect of selected management practices on brittle-snap of corn.

\section{MATERIALS AND METHODS}

Data reported in this paper were collected from a group of crop rotation, cultivar, planting date, and $\mathrm{N}$ fertilizer management experiments established near Shelton, NE $\left(98^{\circ} 46^{\prime}\right.$ $\mathrm{W}, 40^{\circ} 53^{\prime} \mathrm{N}$ ), in the early 1990 s on nearly level irrigated sites. Soil at the site is a Hord silt loam (fine-silty, mixed, mesic Cumulic Haplustolls). The original purpose of the experiments was to evaluate the effect of selected management practices on nitrate leaching to ground water from irrigated cropland as part of the Nebraska Management Systems Evaluation Area (MSEA) project and related experiments.

The main experiment (crop rotation experiment) was designed as a randomized, complete block experiment (4 blocks) with a split-split-plot treatment arrangement. Crop rotations were assigned to whole plots and consisted of continuous corn, corn after soybean, and continuous soybean (the latter treatment is not pertinent to the paper and will not be discussed further). Continuous crops occurred on the same unit of land each year of the experiment; rotated crop treatments were assigned to two units of land (one for each crop in the rotation each year). Crop cultivar treatments were assigned to subplots. Corn hybrids used in the study were Pioneer '3162', '3379', '3394', and '3417' (Pioneer Hi-Bred Int., Johnston, IA). Nitrogen fertilizer treatments were assigned to subsubplots. Levels of $\mathrm{N}$ application were $0,40,80,120$, and 180 $\mathrm{kg} \mathrm{N} \mathrm{ha}{ }^{-1}$ in 1993 and $0,50,100,150$, and $200 \mathrm{~kg} \mathrm{~N}^{-1}$ in 1994. Sub-subplots were eight rows wide $(7.32 \mathrm{~m})$ and $15.25 \mathrm{~m}$

'Mention of commercial products in this paper is solely to provide specific information for the reader. It does not constitute endorsement by the USDA-ARS or the Univ. of Nebraska's Agricultural Research Division over other products which may be suitable. long. Row spacing was $0.91 \mathrm{~m}$. Treatments (except crop rotation) were assigned to the same experimental unit each year of the study. The crop was irrigated with a lateral-move sprinkler system as needed to avoid water deficiency.

Corn was planted 4 May 1993 and 6 May 1994 at about 72000 seeds ha $^{-1}$ in east-west rows. Nitrogen fertilizer treatments were applied at the V3 stage (Ritchie et al., 1986) by uniformly spreading weighed amounts of granular $\mathrm{NH}_{4} \mathrm{NO}_{3}$ by hand on the soil surface on 7 June 1993 and 3 June 1994. Nitrogen was incorporated immediately by applying $7 \mathrm{~mm}$ of water with the irrigation system.

At about V3, 10 consecutive plants in the fourth row from the north border of each sub-subplot were selected and tagged for phenological stage observations. Stage of development for each of these 10 plants, as outlined by Ritchie et al. (1986), was recorded at weekly intervals for the remainder of the season. Averages for the 10 plants were reported as the stage of development for the sub-subplot.

Number of plants and number of broken plants in a 6.1-m segment of row in each sub-subplot were recorded on $15 \mathrm{July}$ 1993 ( 1 wk after the storm). Plants were defined as broken if part of the plant remained below horizontal on the day of observation. On 8 July 1994 ( 1 wk after the storm), percent of 20 consecutive plants that were broken (as defined above) in one row of each plot was recorded.

Plant breakage in two other experiments was also assessed in 1993. These experiments were conducted on sites within $9 \mathrm{~km}$ of the main experiment on the same soil series. The first of these experiments involved treatments of planting date, hybrid, and $\mathrm{N}$ fertilizer rate. Planting dates were 15 April, 30 April, and 15 May 1993; hybrids were Pioneer 3379 and 3417; and $\mathrm{N}$ rates were $0,49,98,147$, and $198 \mathrm{~kg} \mathrm{~N}^{-1}$. In the second experiment, treatments were hybrids (Pioneer ' 3245 ' and 3417$)$ and $N$ rates $(0,61,127,153,184,215,245,276,307$, and $337 \mathrm{~kg} \mathrm{~N} \mathrm{ha}^{-1}$ ). Planting date was 23 April 1993. In both experiments, plots were $12.2 \mathrm{~m}$ long by $9.2 \mathrm{~m}$ wide (rows were $0.76 \mathrm{~m}$ wide, planted north-south). Granular $\mathrm{NH}_{4} \mathrm{NO}_{3}$ was applied 1 June 1993. Both sites were furrow irrigated. On 11 July 1993 (3 d after the storm), number of plants and number of broken plants (as defined above) in two adjacent $11.3 \mathrm{~m}$ lengths of row were counted.

Data were subjected to an analysis of variance. Means for rotations and other treatment factors with only two levels were separated based on the $F$-test. Least significant differences were used to separate hybrid and planting date means if more than two levels of a treatment factor were included in the experiment if the $F$-test was significant. Nitrogen-rate responses were evaluated by linear, quadratic, and cubic orthogonal contrasts. Significance was defined by the 0.05 $\alpha$-level for this study.

\section{RESULTS}

\section{Storms}

During the late afternoon and evening of 8 July 1993, a derecho commenced near the Nebraska-Colorado border (Brandon, NE) at about $1645 \mathrm{~h} \mathrm{CST} \mathrm{and} \mathrm{moved}$ east for about $600 \mathrm{~km}$, reaching into western Iowa at about $2200 \mathrm{~h} \mathrm{CST}$. (Derecho is a meteorological term defined as any family of downburst clusters produced by an extratropical mesoscale convective weather system [Maddox, 1980]; i.e., it is an intense storm with straightline winds of great velocity.) The storm path was about $160 \mathrm{~km}$ wide. Wind speeds of 27 to $45 \mathrm{~m} \mathrm{~s}^{-1}$ were reported within $35 \mathrm{~km}$ of the study sites (NOAA, 1993). The wind direction was westerly. Wind speeds as great as $56 \mathrm{~m} \mathrm{~s}^{-1}$ were reported at York, NE, during the storm. 
Table 1. Analysis of variance for midseason stalk breakage for various rotation, hybrid, and $N$ rate treatments in 1993 and 1994 for corn grown near Shelton, NE.

\begin{tabular}{|c|c|c|c|}
\hline \multirow[b]{2}{*}{ Source } & \multirow[b]{2}{*}{ df } & \multicolumn{2}{|c|}{ Mean squares } \\
\hline & & 1993 & 1994 \\
\hline Block & 3 & 195 & 2556 \\
\hline Rotation (Rot) & 1 & $28079^{* *}$ & 903NS \\
\hline Error $a$ & 3 & 324 & 810 \\
\hline Hybrid & 3 & $6112 * * *$ & $\mathbf{2 5 5 9} * * *$ \\
\hline Hybrid $\times$ Rot & 3 & $2465 * 2 * *$ & 103 NS \\
\hline Error $b$ & 18 & 174 & 206 \\
\hline $\mathbf{N}$ rate & 4 & $1550^{* * * *}$ & $70 \mathrm{NS}$ \\
\hline Linear & 1 & $4761 * * *$ & $195 N S$ \\
\hline Quadratic & $\mathbf{1}$ & $1320 * * *$ & $14 \mathrm{NS}$ \\
\hline Cubic & 1 & $121 N S$ & $70 N S$ \\
\hline$N$ rate $\times$ Rot & 4 & $486^{* *}$ & 84NS \\
\hline $\mathbf{N}$ rate $\times$ Hybrid & 12 & $244 *$ & $38 N S$ \\
\hline$N$ rate $\times$ Rot $\times$ Hybrid & 12 & $73 \mathrm{Ns}$ & 81NS \\
\hline Error $c$ & 96 & 107 & 95 \\
\hline Total & 159 & 507 & 213 \\
\hline
\end{tabular}

Property and crop damage were extensive in the entire area covered by the storm.

A storm with somewhat less wind speed, but still very severe, occurred at the research site on 1 July 1994. Wind speeds of 22 to $27 \mathrm{~m} \mathrm{~s}^{-1}$ were reported within 35 $\mathrm{km}$ of the study sites (NOAA, 1994). The storm occurred between 1730 and $1830 \mathrm{~h}$ CST. This storm had a general wind direction of north. Maximum wind speeds during the storm were estimated at $39 \mathrm{~m} \mathrm{~s}^{-1}$ near Sutton, NE. Crop damage was significant, but not as extensive as in the 1993 storm.

\section{3}

All treatment factors (crop rotation, hybrid, and $\mathrm{N}$ rate), and their two-way interactions, were significant sources of variation for percent plants broken in the 1993 storm in the crop rotation study (Table 1). Al-

Table 2. Mean midseason stalk breakage for various rotation, hybrid, and $N$ rate treatments in 1993 and 1994 for corn grown near Shelton, NE.

\begin{tabular}{|c|c|c|}
\hline \multirow[b]{2}{*}{ Treatment } & \multicolumn{2}{|c|}{ Broken plants } \\
\hline & 1993 & 1994 \\
\hline & $\bar{\tau}$ & ——- \\
\hline \multicolumn{3}{|l|}{ Rotation } \\
\hline Corn-corn & $\mathbf{7 A} \dagger$ & 15A \\
\hline Corn-soybean & 33B & $20 \mathrm{~A}$ \\
\hline \multicolumn{3}{|l|}{ Hybrid } \\
\hline Pioneer hybrid 3162 & $\mathbf{4 A}+$ & $7 \mathbf{A}$ \\
\hline Pioneer hybrid 3379 & $18 B$ & 23B \\
\hline Pioneer hybrid 3394 & $25 \mathrm{C}$ & 17B \\
\hline Pioneer hybrid $\mathbf{3 4 1 7}$ & 33D & $24 \mathrm{C}$ \\
\hline \multicolumn{3}{|c|}{$\mathrm{N}$ rate $\left(\mathrm{kg} \mathrm{ha}^{-1}, 1993 / 1994\right)$} \\
\hline $0 / 0$ & 8 & 16 \\
\hline 40/50 & 19 & 16 \\
\hline $80 / 100$ & 23 & 18 \\
\hline $120 / 150$ & 24 & 20 \\
\hline $180 / 200$ & 25 & 18 \\
\hline & $Q^{* * * * * \leqslant \S}$ & NS§ \\
\hline
\end{tabular}

*:**: Significant at the 0.001 probability level.

$\dagger$ Within columns and within the Rotation treatment factor, means followed by the same letter are not different at $\alpha=0.05$ according to analysis of variance.

\$ Within columns and within the Hybrid treatment factor, means followed by the same letter are not different at $\alpha=0.05$ according to least significant difference.

$\S \mathbf{Q}$, quadratic response according to analysis of variance. though the interactions were significant and treatment responses must be presented within levels of other treatment factors, single-factor means offer useful information about the effect of wind on corn under various management practices. Continuous corn had $7 \%$ broken plants, compared with $33 \%$ for the corn-soybean rotation (Table 2). Breakage ranged from $4 \%$ for Pioneer hybrid 3162 to $33 \%$ for Pioneer hybrid 3417. The quadratic component of total $\mathrm{N}$ rate variance was significant. The two-way interactions of these main effects are shown in Fig. 1. All hybrids suffered greater damage when grown in a corn-soybean rotation than as continuous corn. Also, much greater damage occurred at all $\mathrm{N}$ rates in the corn-soybean rotation than in continuous corn. The $\mathrm{N}$ response for continuous corn was linear $\left(y=2.108+0.056 \mathrm{x}, r^{2}=0.82, P<0.0001\right)$. For corn rotated with soybean, the situation was far more complex; the linear $(P<0.0001)$, quadratic $(P<0.0023)$, and cubic $(P<0.0834)$ components of variance were
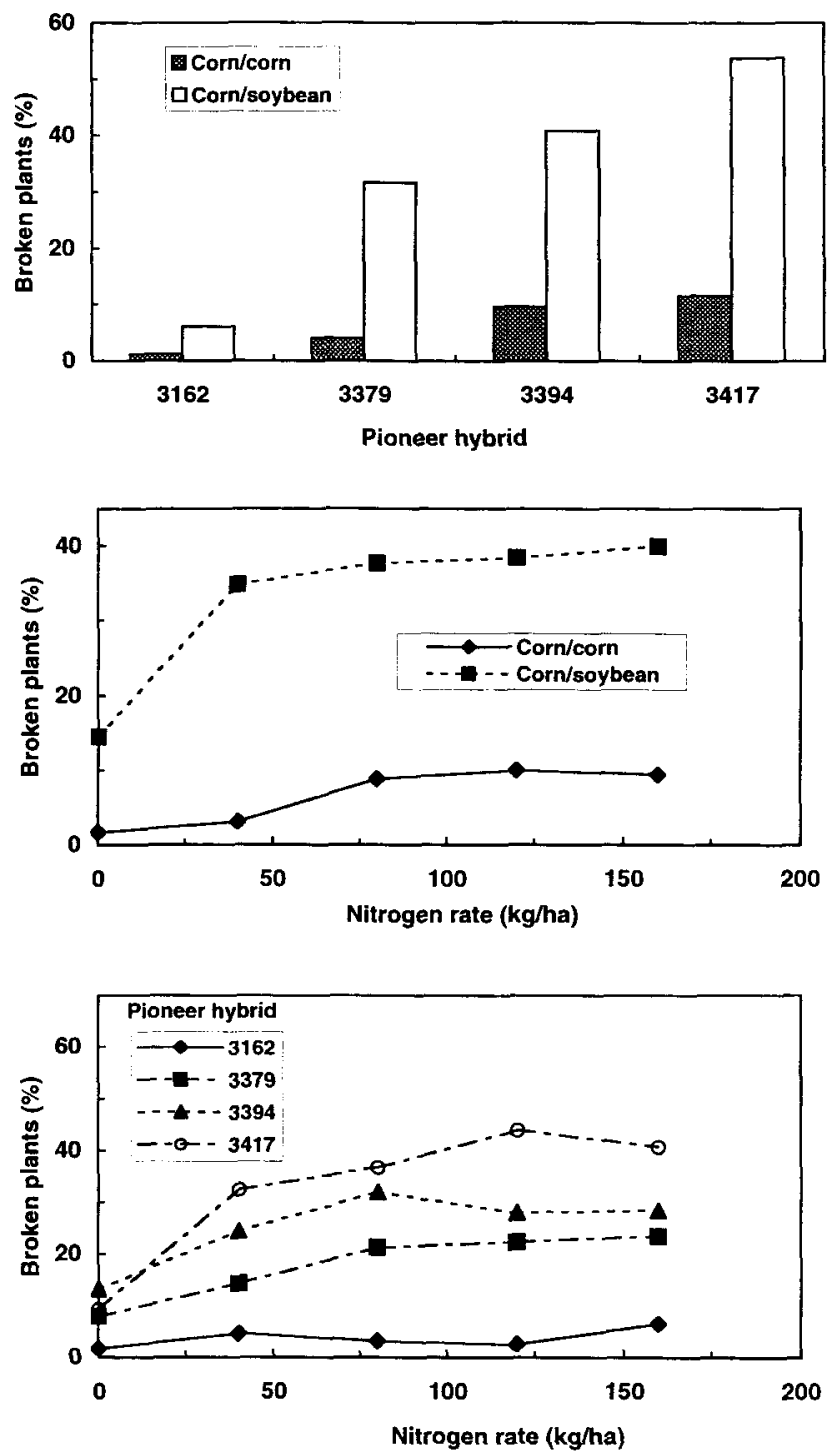

Fig. 1. Response of corn to wind in 1993 near Shelton, NE, for several levels of crop rotation, hybrid, and $\mathbf{N}$ rates in the crop rotation study. 
important in describing the $\mathrm{N}$ response. The majority of the $\mathrm{N}$ response was linear $\left(r^{2}=0.67\right)$. Adding the quadratic component accounted for $92 \%$ of the $\mathrm{N}$ response; further adding the cubic component explained $99 \%$ of the variation. The cubic response is represented by $y=14.628+0.7494 x-0.0075 x^{2}+0.00002 x^{3}$. Note that both the rotation $\times$ hybrid and rotation $\times \mathrm{N}$ rate interactions were caused by an increased magnitude of damage for the rotated corn compared with the continuous corn, and not by a reversal in response. All hybrids responded to $\mathrm{N}$ rate, but the type of response differed for specific hybrids; Pioneer hybrids 3379, 3394, and 3417 had a linear response, whereas Pioneer hybrid 3162 displayed a cubic response (although it had a very minimal increase with increased $\mathrm{N}$ rate; Fig. 1). Differences among hybrids and greater damage with greater $\mathrm{N}$ application rates were also found in the hybrid $\times \mathrm{N}$ rate experiment (Fig. 2). The hybrid $\times \mathrm{N}$ rate interaction was significant at $P<0.06$. Again, the interaction was caused by a difference in magnitude of brittle-snap between Pioneer hybrids 3245 and 3417, not a difference in the type of response. Both hybrids showed a linear increase in brittle-snap as $\mathrm{N}$ rate increased.

Stage of development differed for the same factors as for stalk breakage (i.e., rotation, hybrid, $\mathrm{N}$ rate, and all the two-way interactions except hybrid $\times$ rotation) (Table 3) and strongly affected amount of stalk breakage. Pattern of response to treatment factors was similar for stalk breakage and stage of development determined $2 \mathrm{~d}$ prior to the storm $(r=0.55, n=160, P<0.001)$.

In the planting date experiment, hybrid, planting date, $\mathrm{N}$ rate, and the planting date $\times \mathrm{N}$ rate interaction were significant sources of variation, but the hybrid $\times N$ rate and hybrid $\times$ planting date interactions were not. Pioneer hybrid 3417 had more stalk breakage $(27 \%)$ than Pioneer hybrid $3379(17 \%)$. Damage decreased as planting date was delayed (15 April, 45\%; 30 April, $18 \% ; 15$ May, $3 \%$ ) and increased linearly as applied $\mathrm{N}$ increased. The interaction between planting date and $\mathrm{N}$ rate occurred because corn planted earlier had a greater increase in stalk breakage as $\mathrm{N}$ rate increased than corn planted later (Fig. 3). The response to planting date

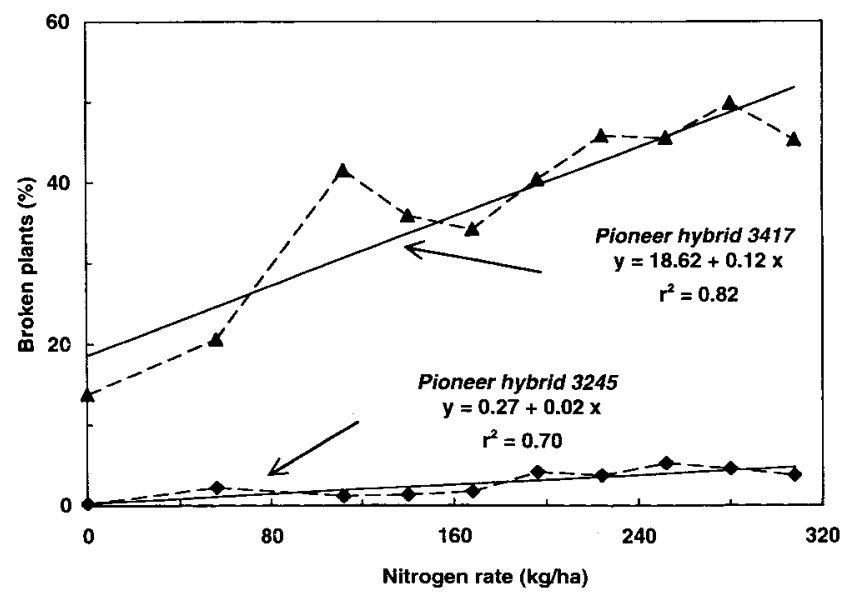

Fig. 2. Response of two corn hybrids grown at several $\mathbf{N}$ rates to wind occurring on 8 July 1993 near Shelton, NE, in the second $\mathbf{N}$ rate study.
Table 3. Analysis of variance for phenological stage for various rotation, hybrid, and $N$ rate treatments for corn grown near Shelton, NE near the time midseason stalk breakage occurred in 1993 and 1994.

\begin{tabular}{|c|c|c|c|}
\hline \multirow[b]{2}{*}{ Source } & \multirow[b]{2}{*}{ df } & \multicolumn{2}{|c|}{ Mean squares } \\
\hline & & 6 July 1993 & 28 June 1994 \\
\hline Block & 3 & 14.66 & 0.76 \\
\hline Rotation (Rot) & 1 & $90.30^{* * * 3 k}$ & $11.40^{* * *}$ \\
\hline Error $a$ & 3 & 0.15 & 0.19 \\
\hline Hybrid & 3 & $2.65^{* * 3 k}$ & 0.39 Ns \\
\hline Hybrid $\times$ Rot & $\mathbf{3}$ & $0.98 \mathrm{NS}$ & $0.48 \times s$ \\
\hline Error $b$ & 18 & 0.37 & 0.18 \\
\hline N rate & 4 & $1.46^{* * * * *}$ & 0.03 Ns \\
\hline Linear & $\mathbf{i}$ & $0.48 * * * *$ & $0.05 \mathrm{Ns}$ \\
\hline Quadratic & 1 & $\mathbf{0 . 1 3} *$ & $0.02 \mathrm{Ns}$ \\
\hline Cubic & $\mathbf{1}$ & $0.29^{*}$ & $0.05 \mathrm{NS}$ \\
\hline N rate $\times$ Rot & 4 & 0.56 6**** & 0.07 NS \\
\hline $\mathbf{N}$ rate $\times$ Hybrid & 12 & $0.21 * *$ & $0.14^{*}$ \\
\hline$N$ rate $\times$ Rot $\times$ Hybrid & 12 & $\mathbf{0 . 1 8}$ & $0.06 \mathrm{Ns}$ \\
\hline Error $c$ & 96 & 0.09 & 0.07 \\
\hline Total & 159 & 1.09 & 0.19 \\
\hline
\end{tabular}

supports the concept that susceptibility to stalk breakage is related to developmental stage. Elmore and Ferguson (1996) also reported that the amount of brittlesnap is related to crop development.

\section{4}

Data collected after the 1994 storm were somewhat different from those collected in 1993, in that only the hybrid effect was significant (Table 1). Stalk breakage was $7 \%$ for Pioneer hybrid 3162, 23\% for Pioneer hybrid $3379,17 \%$ for Pioneer hybrid 3394 , and $24 \%$ for Pioneer hybrid 3417 (Table 2). Phenological development did not differ among hybrids $3 \mathrm{~d}$ before the storm (28 June 1994; Table 3). Corn grown in rotation with soybean was at stage V11.3, compared with V10.8 for continuous corn (Table 4). The significant $\mathrm{N}$ rate $\times$ hybrid interaction for phenological development occurred because Pioneer hybrid 3379 developed more slowly at all $\mathrm{N}$

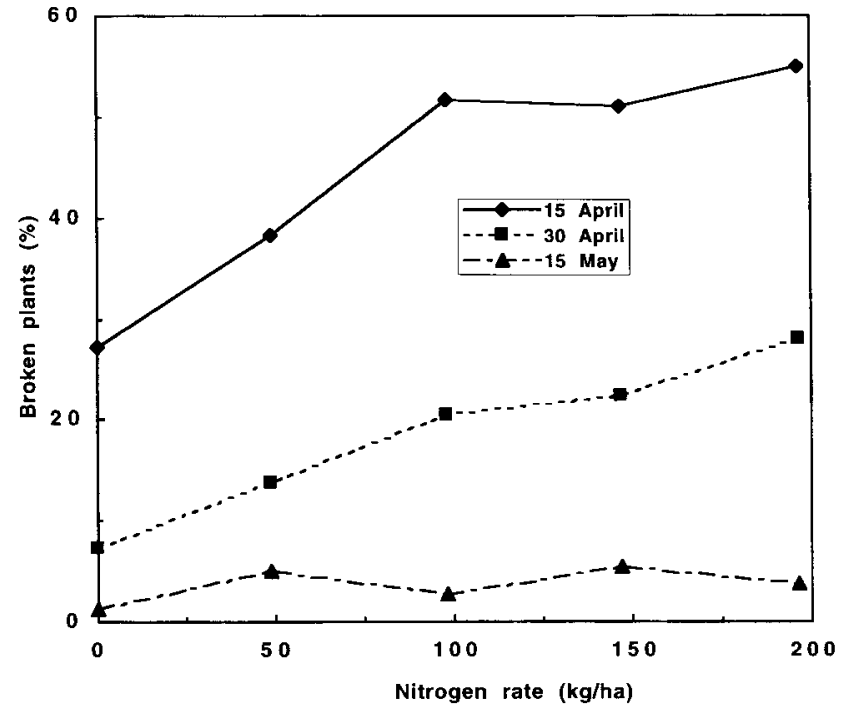

Fig. 3. Mean response of two corn hybrids (Pioneer hybrids 3379 and 3417) at several $N$ rates and planting dates to wind occurring 8 July 1993 near Shelton, NE. 
rates, except $200 \mathrm{~kg} \mathrm{~N} \mathrm{ha}^{-1}$ (data not shown). Part of the reason for the great difference between the effects of the two storms may be that the 1993 storm had westerly winds but the 1994 storm had northerly winds.

\section{DISCUSSION}

Stage of development strongly influenced brittlesnap. Apparently, there is a period, just before tasseling, when corn is more susceptible to breaking in strong winds. Just prior to tasseling, internodes are growing rapidly and tissues at the base of elongating internodes are immature. Field observations of broken stalks confirmed that the plate of dividing or enlarging cells in the intercalary meristem at the base of the internode is the point of breakage. Elmore and Ferguson (1996) reported similar observations. Greater knowledge of the cell structure in this region of growth and differences in the structure of susceptible (i.e., Pioneer hybrid 3417) and resistant (i.e., Pioneer hybrid 3162) hybrids can increase our understanding of how and why breakage occurs. Li (1997) suggested that the greater percentage of intercellular space within the pith parenchyma of Pioneer hybrid 3417, compared with Pioneer hybrid 3162 , may explain its greater susceptibility to brittlesnap.

The great difference in amount of stalk breakage between corn grown continuously and that rotated with soybean and among corn grown with different rates of $\mathrm{N}$, and the fact that in the past many researchers have attributed the growth and yield enhancement associated with rotation of corn and soybean to greater availability of N (Baldock et al., 1981; Baldock and Musgrave, 1980), suggests that the effect of rotation on stalk breakage may be simply an extension of the $\mathrm{N}$ rate effect. Residual soil nitrate levels ( 0 to $1.5 \mathrm{~m}$, averaged over hybrids and

Table 4. Mean phenological stage (Ritchie et al., 1986) for various rotation, hybrid, and $\mathbf{N}$ rate treatments for corn grown near Shelton, NE, in 1993 and 1994 near the time the midseason stalk breakage event occurred.

\begin{tabular}{|c|c|c|}
\hline \multirow[b]{2}{*}{ Treatment } & \multicolumn{2}{|c|}{ Phenological stage } \\
\hline & 6 July 1993 & 28 June 1994 \\
\hline \multicolumn{3}{|l|}{ Rotation } \\
\hline Corn-corn & $9.1 \mathrm{~A} \dagger$ & $10.8 \mathrm{~A}$ \\
\hline Corn-soybean & $10.6 \mathrm{~B}$ & $11.3 B$ \\
\hline \multicolumn{3}{|l|}{ Hybrid } \\
\hline Pioneer hybrid 3162 & $9.5 B$ & $11.2 \mathrm{~A}$ \\
\hline Pioneer hybrid $\mathbf{3 3 7 9}$ & $10.0 \mathrm{~A}$ & 11.0A \\
\hline Pioneer hybrid 3394 & 10.1A & 11.0A \\
\hline Pioneer hybrid 3417 & $9.9 \mathrm{~A}$ & 11.1A \\
\hline \multicolumn{3}{|c|}{$\mathrm{N}$ rate $\left(\mathrm{kg} \mathrm{ha}^{-1}, 1993 / 1994\right)$} \\
\hline $0 / 0$ & 9.5 & 11.0 \\
\hline $40 / 50$ & 9.9 & 11.1 \\
\hline $80 / 100$ & 9.9 & 11.1 \\
\hline $\mathbf{1 2 0 / 1 5 0}$ & 9.9 & 11.0 \\
\hline \multirow[t]{2}{*}{$180 / 200$} & 10.1 & 11.1 \\
\hline & $\mathbf{L}^{* * * * * \S} \S$ & NS \\
\hline
\end{tabular}

\footnotetext{
**** Significant at the 0.001 probability level.
}

$\dagger$ Within columns and within the Rotation treatment factor, means followed by the same letter are not different at $\alpha=0.05$ according to analysis of variance.

\$ Within columns and within the Hybrid treatment factor, means followed by the same letter are not different at $\alpha=0.05$ according to least significant difference.

$\$ \mathrm{~L}$, linear response, according to analysis of variance.
$\mathrm{N}$ rates) before planting in 1993 were similar: $77 \mathrm{~kg} \mathrm{~N}$ $\mathrm{ha}^{-1}$ for the continuous corn treatment and $63 \mathrm{~kg} \mathrm{~N}$ $\mathrm{ha}^{-1}$ for the corn-soybean rotation treatment. In 1994, residual nitrate levels were slightly greater $(81 \mathrm{~kg} \mathrm{~N}$ $\mathrm{ha}^{-1}$ for the continuous corn treatment and $112 \mathrm{~kg} \mathrm{~N}$ $\mathrm{ha}^{-1}$ for the corn-soybean rotation treatment), but stalk breakage did not differ between the crop rotation treatments. Residual soil nitrate level comparisons between the rotation treatments do not support the $\mathrm{N}$ rate hypothesis suggested above. In 1993, when crop rotations differed in amount of breakage, rotations differed less than $10 \%$ in amount of residual soil nitrate, and the treatment with the greater level of residual nitrate had the least breakage. In 1994, when residual nitrate ranged $31 \mathrm{~kg} \mathrm{~N}^{-1}$, the crop rotations did not differ for stalk breakage. It is likely that other factors in the rotation effect associated with enhanced crop growth are involved in the explanation (Heichel and Barnes, 1984).

The devastating impact of brittle-snap is related to at least four factors. First, if the stalk breaks below the uppermost ear node, yield potential is severely reduced. If ear shoots at nodes below the break do not emerge when pollen is shedding, yield potential of broken plants is reduced to zero. Second, tassels of all broken plants are rendered ineffective, either because pollen will not develop and shed normally or because the tassel is on the ground or below the silks. A portion of the plants in affected fields survived these storms without breaking, but not without some loss of yield potential. As the number of broken plants increases, the amount of pollen in the field is reduced and the kernel set on nonbroken plants may be reduced. Elmore and Ferguson (1996) reported that nonbroken plants do not compensate for the yield loss resulting from brittle-snap. Third, leaf area of the crop is reduced. On plants that break above the primary ear shoot, the loss of upper leaves will reduce leaf area index, light interception, and yield potential. With reduced crop leaf area and greater light penetration into the canopy, weed growth is enhanced, further reducing yield and increasing harvest problems. More weeds result in a greater weed seed bank for next season. Fourth and last, broken plants are more susceptible to invasion by pathogens and insects, potentially reducing grain yield and quality and increasing harvest losses.

Although the impact of the two storms differed, the amount of brittle-snap differed among hybrids in both years. Ranking of the four hybrids in the rotation study differed between years, but the hybrid with the least breakage (Pioneer 3162) and the one with the greatest damage (Pioneer 3417) remained the same. The difference in amount of damage to the hybrids in the two storms may be related to the developmental stage of the hybrids at the time of the storm, but hybrids did not differ in developmental stage in 1994. Pioneer 3417 is the earliest maturing of the hybrids included in the study, with a comparative maturity rating (CMR) of 109, compared with 111, 111, and 114 CMR for Pioneer hybrids 3394, 3379, and 3162, respectively. Silking CMR values for Pioneer hybrids 3417, 3394, 3379, and 3162 are $108,111,113$, and 112 , respectively. These values indicate that, even though the hybrids were at compara- 
ble leaf stages (i.e., had a similar number of fully expanded leaves; Table 4) at the time of the storm, Pioneer hybrid 3417 (because it produces fewer leaves in total; data not shown) was actually at a later developmental stage (i.e., nearer tasseling) than the other hybrids.

In conclusion, management practices that resulted in more rapid growth of the corn (optimum to excessive $\mathrm{N}$ fertilizer rates, corn-soybean rotation, and early planting-which, for the area of the study, was 20 to 30 April) increased susceptibility to brittle-snap. However, the great difference in brittle-snap among hybrids averaged across management practices indicates that selection of a brittle-snap resistant or moderately resistant hybrid may be the most effective way for producers to protect against this catastrophe. Although not conclusive, differences among hybrids suggest that selection for resistance to brittle-snap may be possible. For selection in a breeding program to be effective, methods to simulate brittle-snap must be developed. Finally, we must learn more about differences in cell and tissue structures and growth rates between resistant and susceptible hybrids and heritability of important traits related to brittle-snap resistance to aid selection in breeding programs.

\section{REFERENCES}

Baldock, J.O., R.L. Higgs, W.H. Paulson, J.A. Jackobs, and W.D. Shrader. 1981. Legume and mineral $\mathrm{N}$ effects on crop yields in several crop sequences in the upper Mississippi Valley. Agron. J. 73:885-890.

Baldock, J.O., and R.B. Musgrave. 1980. Effects of manure and mineral fertilizer on continuous and rotational crop sequences. Agron. J. 72:511-518.

Elmore, R.W., and R.B. Ferguson. 1996. Brittle-snap in corn: Hybrid and environmental factors. p. 139-150. In Proc. Corn and Sorghum Res. Conf., 51st, Chicago. 10-12 Dec. 1996. Am. Seed Trade Assoc., Washington, DC.

Heichel, G.H., and D.K. Barnes. 1984. Opportunities for meeting crop nitrogen needs from symbiotic nitrogen fixation. p. 49-59. In D.F. Bezdicek et al. (ed.) Organic farming: Current technology and its role in a sustainable agriculture. ASA Spec. Publ. 46. ASA, CSSA, and SSSA, Madison, WI.

Laukaitis, A.J. 1994. Storm blew straight into record book. Lincoln (Nebr.) Journal Star, 3 July 1994, p. 1A, col. 1.

Li, M. 1997. Anatomical and morphological characteristics of maize genotypes varying in resistance to brittle-snap. M.S. thesis. Univ. of Nebraska, Lincoln.

Maddox, R.A. 1980. Mesoscale convective complexes. Bull. Am. Meteorol. Soc. 61:1374-1387.

NOAA. 1993. Storm data and unusual weather phenomena. Storm Data 35(7):177-183.

NOAA. 1994. Storm data and unusual weather phenomena. Storm Data 36(7): $130-135$.

Ohle, B. 1993. Aftermath of the July 8 "greensnap." Nebraska Farmer (October 1993):10-11.

Pioneer Hi-Bred International, Inc. 1996. Technology that yields. Pioneer Hi-Bred Int., Johnston, IA.

Ritchie, S.W., J.J. Hanway, and G.O. Benson. 1986. How a corn plant develops. Rev. ed. Iowa State Univ. of Sci. and Technol.-Coop. Ext. Serv. Spec. Rep. 48. 